\title{
MUSLIM WOMEN'S EXPERIENCES OF DOMESTIC VIOLENCE IN THE NELSON MANDELA METROPOLE: A QUALITATIVE STUDY
}

\author{
Ms Razia Nordien
}

MA (Clinical Social Work)

Social Worker Gelvandale High School, Port Elizabeth

\section{Dr Nicky Alpaslan}

D Phil (Social Work)

Senior Lecturer Department of Social Development Professions, University of Port Elizabeth

Corresponding author: swaaha@upe.ac.za

\author{
Ms Blanche Pretorius \\ MA (Clinical Social Work) \\ Lecturer Department of Social Development Profession University of Port Elizabeth
}

Keywords: Domestic violence; experiences of Muslim women; feelings; precipitating factors; coping mechanisms

\begin{abstract}
This article provides a reflection on the experiences of Muslim women with regard to domestic violence. $A$ qualitative approach was utilised following an explorative, descriptive, phenomenological contextual research design, as the researchers sought to understand the lived experiences of Muslim women in abusive relationships. The method of data collection included semi-structured interviews, as this was most appropriate to the nature of the study. Data-analysis was done according to the steps for qualitative data-analysis as proposed by Tesch in Creswell (1994). Guba's model (in Krefting, 1991) was employed for assessing the trustworthiness of qualitative data and for data-verification. The research findings centred on the following six themes: 1) Types of abuse experienced by participants; 2) Feelings/emotional reactions experienced by participants as a result of the abuse; 3) Precipitating factors contributing to domestic violence experienced by participants; 4) Motivation for maintaining abuse relationships; 5) Coping mechanisms to remain in or leave the relationship; and 6) Advice from participants to others in abusive relationships. The recommendations resulting from this research project proposed inter alia that the Muslim community be sensitised to the reality of domestic violence in Muslim marriages, and that support structures and service networks be put in place to attend to the needs of the women falling prey to domestic violence.
\end{abstract}

\section{OPSOMMING}

Hierdie artikel werp 'n blik op Moslemvroue se ervarings van huweliksgeweld. Binne die kwalitatiewe navorsingsbenadering is ' $n$ verkennende, beskrywende, fenomenologies kontekstuele navorsingsontwerp gevolg om die navorsers te help om tot begrip te kom van die deurleefde ervaring van Moslemvroue in gewelddadige verhoudings. Data is aan die hand van semi-gestruktureerde onderhoude ingesamel. Data-ontleding is uitgevoer volgens die stappe van kwalitatiewe data-ontleding soos voorgestel deur Tesch in Creswell (1994). Guba se model (in Krefting, 1991) is benut vir die assessering van die vertrouenswaardigheid van die kwalitatiewe data en vir dataverifiëring. Die navorsingsbevindinge het rondom die volgende ses temas gesentreer: 1) Vorme van geweld ervaar deur die deelnemers; 2) Gevoelens/emosionele reaksies ervaar deur die deelnemers as ' $n$ gevolg van die geweld; 3) Faktore wat aanleiding gegee het tot die huweliksgeweld; 4) Die motivering om die gewelddadige verhouding in stand te hou; 5) Hanteringsmeganismes om in die verhouding te bly of dit te verlaat; 6) Advies van die deelnemers aan andere in gewelddadige verhoudings. Voortspruitend uit die navorsing is die volgende aanbevelings gemaak: die Moslem-gemeenskap moet ingelig word oor die voorkoms van 
huweliksgeweld in Moslemhuwelike. Ondersteuningstrukture en -netwerke moet in plek gestel word wat aandag kan skenk aan die behoeftes van vroue wat slagoffers van huweliksgeweld kan raak.

\section{INTRODUCTION AND PROBLEM FORMULATION}

Domestic violence is a social phenomenon that is universal and pervades society at all levels (Tshiwula, 1999:80). Domestic violence is one of the commonest crimes and is present throughout society, usually hidden, but there nonetheless (Hague \& Malos, 1998:1). According to Vincent and Jouriles (2000:7), violence towards women by an intimate partner is a social problem of enormous proportions. Domestic violence, according to the Domestic Violence Act 116 of 1998, is defined as: "physical abuse; sexual abuse; emotional, verbal and psychological abuse; economic abuse; intimidation; harassment; stalking; damage to property; entry into the complainant's residence without consent where the parties do not share the residence; or any other controlling or abusive behaviour towards a complainant, where such conduct harms, or may cause imminent harm to the safety, health or well-being of the complainant".

The impact of this violence is broad and substantial, with serious consequences not only for the women who are victimised, but also for their children and society at large. People often use religion and culture to explain or rationalise violence against women. Umme Faruah Imam (in Park, Fedler \& Dangor, 2000:256) states that "religion and culture have been used universally by men to maintain their power over women and to justify misogyny and chauvinism". Men justify the abuse by manipulating religion and culture.

In the society, the family is symbolised as a place of affection, love and nurturance, but it is in fact the place where violence is most tolerated (Chang, 1996:15). Domestic violence is alive and well in Muslim marriages, and a recent sermon presented by a Sheikh at the end of December 2000 has attested to this. Prior to this, on 17 November 2000, a seminar on family violence was presented in the community at which a psychologist and a Sheikh spoke about the prevalence of domestic violence within the Muslim community. According to them, the rate of domestic violence in this Muslim community is increasing quite rapidly, and this is apparent from the number of women who seek assistance from Muslim leaders with regard to domestic violence.

It appears to be a commonly held perception that in Islam, women have no rights, and that subordination and servitude are the role of the wife. This is in direct contrast to what the Qur'an advocates. Syed Ameer Ali (in Chaundry, 1991:6) sums up the status of a woman, as wife, in Islam, in the following words: "on her marriage she does not lose her individuality, and she does not cease to be a separate member of society". Some people have erroneously concluded that Islam has issued an unrestricted licence in favour of husbands resorting to beating their wives (Syed Ameer Ali, in Chaundry, 1991:16).

Islam requires that husbands treat their wives with respect, and prohibits any form of physical or emotional abuse. According to the Quraan Study and Research Foundation (1999:102), the Holy Prophet is reported to have said, "amongst the rights of a woman which must be respected is that she will be well-educated, treated with dignity and respect, supported, fed, clothed, protected and never be insulted or assaulted".

Tragically, in the abusive mindset, Muslim men ignore these verses and misquote the Qur'anic verse that says men are the protectors and maintainers of women, to justify complete control of females (Alkhateeb, 2001:http://www.steppingtogether.org/ article).

Despite the severity of the problem, the Muslim community has largely closed its eyes, and has devoted very few resources, such as support structures and counselling services, to helping the victims and stopping the abusers.

Wife abuse, which stretches across all ethnic, racial, educational and socio-economic strata in the Muslim community, results in severe emotional and physical pain for many Muslim women and many weak, unhappy Muslim families that fail to contribute adequately to the development of the Muslim community (Memon, n.d.: http://www.steppingtogether. 
org/article).

As far as could be ascertained, research of this nature has not been undertaken in the Nelson Mandela Metropole. Whilst conducting a literature search on the databases Nexus, SAS, SSA, EBSCO HOST, and Dissertation Abstracts Online, many articles on domestic violence in Islam have been found internationally. Examples of these articles are: "Wife Abuse in the Muslim Community" by Memon (n.d.: http://www.stepping-together.org/article); "An Islamic Perspective on Violence Against Women" (Anonymous, 2001:http://www.zawaj.com/articles/ violence); "Wife Beating?" by Badawi, (n.d.:http:// www.zawaj.com/articles/badawidomestic.html); "Authority and the abuse of Power in Muslim Marriages" by Hendricks (n.d.: http://www.zawaj.com/ articles/marriage abuse power.html) and "Muslims against Family Violence" (Anonymous, n.d.: http:// www.stepping-together.org/projects mafv.html).

No specific research of this nature within the ambit of social work was located on a national level. One research thesis has been found on "Battered Women in Muslim Communities: Religious Construction of Gender, Marriage and Sexuality" (Shaikh, 1996). This research was approached more from a religious point of view than focusing on the experiences of abused women themselves. It is therefore clear that the present research can be useful to significant members in the community; in providing information that could contribute to improving services to Muslim women affected by domestic violence.

From the above introduction, the following problem statement and justification for this particular research undertaking can be derived:

In view of misinterpretations of Islamic principles, the incidence and severity of domestic violence, in the context of Muslim marriages, is often not acknowledged. This has resulted in a lack of resources aimed at either assisting victims or intervening against perpetrators.

The aim of this research endeavour will be to provide victims the opportunity to articulate their lived experiences of domestic violence, and based on such first-hand information, professionals will be in a posi- tion to initiate more appropriate interventions.

Furthermore, these insights will enhance the indigenous professional knowledge-base on this topic.

\section{RESEARCH QUESTION}

De Vos and Fouché (in De Vos, Strydom, Fouché, Poggenpoel, Schurink \& Schurink, 1998:116) are of the opinion that research questions are relevant in qualitative studies, whereas hypotheses are more likely to be used in quantitative research. The research question, which forms the central focus of this study, can be stated as follows: What are the experiences of Muslim women in the Nelson Mandela Metropole region with regard to domestic violence?

\section{THE QUALITATIVE RESEARCH PROCESS}

Rothery, Thomlinson and Grinnell in De Vos et al. (1998:19) define research as "a structured enquiry that utilises acceptable scientific methodology to solve problems and create new knowledge that is generally acceptable".

The term "methodology" defines how one will go about studying any phenomenon (Silverman, 2000:79). Qualitative research is naturalistic, holistic and inductive, meaning that phenomena are studied in their natural settings, without manipulation, and as interrelated wholes (Terre Blanche \& Durrheim, 1999:43). The qualitative research process is flexible and unique, and evolves throughout the research process. There are no fixed steps that should be followed, and contrary to the quantitative research design, which is standardised according to a fixed procedure, qualitative research cannot be exactly replicated (Neuman, 1994; Denzin \& Lincoln, 1994 in De Vos et al. 1998:243). Qualitative researchers employ a wide range of interconnected methods, aiming to develop a greater understanding of the phenomena at hand (Denzin \& Lincoln, 1998:3).

In De Vos et al. (1998:29-50), various authors have outlined various phases of the qualitative research process. For the purposes of this study, the researchers have decided to use De Vos' framework of the qualitative research process as offered in De Vos et al. (1998:44-45), as it incorporates the views of a 
number of authors, and provides the researcher with a logical structure.

The phases of the qualitative research process, as outlined by De Vos (in De Vos et al. 1998:44-45) are: Phase One: Choice of a research problem, topic or theme;

Phase Two: Decision on the qualitative choice; Phase Three: Selection of the qualitative design; Phase Four: Preparation for data collection; Phase Five: Data collection and analysis;

Phase Six: Data verification, and

Phase Seven: Report writing.

In the ensuing discussion, each of these phases will be briefly described as applied to the research project.

\section{Phase One: Choosing the research problem}

Phase one has already been discussed in the introductory section.

\section{Phase Two: Deciding to use a qualitative approach}

Strauss and Corbin (1998:10-11) define qualitative research as: "any type of research that produces findings not arrived at by statistical procedures or their means of quantification. It can refer to research about persons' lives, lived experiences, behaviors, emotions, and feelings as well as about organizational functioning, social movements, cultural phenomena, and interaction between nations". A qualitative approach is followed when the researcher attempts to gain a first-hand, holistic understanding of phenomena of interest by means of a flexible strategy of inquiry (Reid \& Smith, 1981 in De Vos et al. 1998:71).

The researchers intended to research and interpret the lived experiences of abused women, thus adopting a qualitative research design following an explorative, descriptive, phenomenological, contextual strategy of inquiry.

Phase Three: Selecting the qualitative
research design
The concept "research design" is identified by Sellitz, Jahoda, Deutsch and Cook (in Terre Blanche \& Durrheim, 1999:29) as "plans that guide the arrangement of conditions for collection and analysis of data in a manner that aims to combine relevance to the research purpose with economy in procedure". Le Compte and Preissle (in Denzin \& Lincoln, 1998:28) describe a "research design" as involving a clear focus on the research question, the purposes of the study, what information will most appropriately answer specific research questions, and which strategies are most effective for obtaining it. Denzin and Lincoln (1998:29) identified various strategies of inquiry that could be used in qualitative research. The researchers chose an explorative, descriptive, phenomenological, contextual strategy of inquiry for the research conducted,

Phenomenology is the approach that aims to emphasise a focus on people's subjective experiences and interpretations of their world (Rubin \& Babbie, 1997:376). Exploratory studies attempt to investigate unknown areas of research, and employ an open, flexible and inductive approach, looking for new insights into phenomena, whereas descriptive approaches aim to describe phenomena accurately (Terre Blanche \& Durrheim, 1999:39). According to Best (in Cohen \& Manion 1994:67), descriptive research is concerned with conditions or relationships that exist; practices that prevail; beliefs, points of view, or attitudes that are held; processes that are going on; effects that are being felt; or trends that are developing. At times, descriptive research is concerned with how what is or what exists is related to some preceding event that has influenced or affected a present condition or event. Contextual studies seek to avoid the separation of participants from the large context to which they may be related (Schurink in De Vos et al. 1998:281).

The researchers selected this strategy of inquiry, as it was their intention to explore, describe and interpret the lived experiences of Muslim women being abused in their intimate (marital) relationships.

\section{Phase four: Preparing for data collection}

This phase embraced several decisions that were executed before the implementation of data collection 
(phase five). It included the following:

- Identifying boundaries or parameters for data collection, including the setting. The setting was delineated as the Muslim community in the Nelson Mandela Metropolitan area. The interviews were conducted at the homes of the participants, which were most convenient for them.

- The actors or informants who were interviewed were Muslim women in abusive marital relationships. Purposive and snowball sampling were used, based on the assumption that participants would be selected because they were believed to be able to give the researchers access to some specialised insight, perspective or experience (Yegidis \& Weinbach, 1996:122). A heterogeneous sample was selected according to the following criteria:

- Muslim women who have experienced domestic violence in the context of a marital relationship

- Muslim women of different ages

- Muslim women from different economic backgrounds and different educational levels.

Six women were interviewed. The researcher who undertook the fieldwork gained entry into the setting with the aid of numerous gatekeepers. The gatekeepers were a social worker at PE Childline and Family Welfare and five prominent ladies in the Muslim Community.

- The role of the researcher/fieldworker in this study can be described as participant-asobserver. In this role she interacted closely enough with participants to get an insider view. (Compare Gold in De Vos et al. 1998:260.)

- Considering and preparing for the use of gatekeepers involved making contact with the gatekeepers. The researcher/fieldworker telephonically explained to the gatekeepers the purpose of the research, how the research would be undertaken, and what would happen with the results of the study. Afterwards the gatekeepers met with the researcher/fieldworker, and were presented with letters detailing the research process to be undertaken. The gatekeepers approached possible participants, explained the purpose of the study to them, and gained their participation in the study.

- With regard to the events and process, the researcher/fieldworker then met with participants individually and explained the purpose of the study and the research procedures to them. The researcher/ fieldworker also explained that it would be necessary to tape-record the interviews, as well as to take notes during the interviews. This would be done with their permission. The researcher/fieldworker explained to them that all information (tapes and notes) would be destroyed once the research was completed. A time and venue were arranged to suit the participants. A letter to each participant followed the face-to-face conversation. In the letter the researcher addressed issues of confidentiality and voluntary participation. Each participant was asked to sign two copies of a voluntary consent form, prior to the actual interviews. Once the participants expressed their willingness to participate in this research study, they were asked to complete the consent forms.

- The researcher/fieldworker designed a tentative protocol to note observations in the field, namely a single page with a dividing line down the centre, separating descriptive and reflective notes which would serve as a guideline for the organisation of raw data obtained during interviews. The interviews were audiotaped, allowing the researchers to capture the richness and subtleties of the speech of the person being interviewed (compare Tutty, Rothery \& Grinnell, 1996:6).

- A pilot study was undertaken in preparation for the research process. The first interview conducted with the first participant served as a pilot study. On completion of the interview, the researchers evaluated the questions and the process.

- The method of data collection employed by the researcher/fieldworker was in-depth semistructured interviewing. A semi-structured interview makes use of some pre-determined questions or key words used as a guide (Tutty 
et al. 1996:56). The statements/questions were asked in an open-ended manner at appropriate times. The questions were:

1. Tell me more about the experience of domestic violence in your marriage.

2. Tell me how you cope with this violence.

3. What advice or suggestions would you recommend for women in similar situations?

\section{Phase Five: Data analysis}

Data analysis can be described as "a search for patterns in data-recurrent behaviours, objects or a body of knowledge" (Neuman, 1994:426). Interviews were transcribed verbatim immediately after they were completed (De Vos in De Vos et al. 1998:48). The data was then analysed according to the eight steps proposed by Tesch (in Creswell, 1994:154-155).

\section{Phase Six: Data verification}

Data verification involves checking the collected data for biases that might affect the process of drawing conclusions (Poggenpoel in De Vos et al. 1998:351). The process of data verification was carried out according to Guba's model of trustworthiness (in Krefting, 1991:215), which identifies four criteria and strategies for ensuring and establishing trustworthiness, and which are therefore used to assess the qualitative research process undertaken.

The first criterion addressed in establishing trustworthiness, is that of truth value, that is, determining to what extent the findings are a true reflection of the life experiences of Muslim women who have been abused, as experienced by them. The strategy for establishing truth value is credibility. The particular actions taken to achieve credibility included reflexivity, peer examination, interviewing techniques, member checking, and triangulation (that is, triangulation of data sources).

The second criterion is applicability or the degree to which findings can be applied to other contexts or settings and groups (that is, generalisability). Transferability was the strategy employed to attain applicability. Transferability was achieved by document- ing dense descriptions of the research methodology and by working contextually so that procedures could be duplicated accurately.

The third criterion of Guba's model (in Krefting, 1991:215-222) is termed consistency, which is concerned with the extent to which the replication of the study in a similar context or with similar informants will produce the same results. Dependability was the strategy used to ensure consistency. The actions that were taken to ensure dependability in this case included: peer examination, a dense description of the research methodology, triangulation of data sources, and conducting a code-recode procedure.

Neutrality is the fourth and final criterion, and refers to the extent to which the study's findings are free from bias. Guba in Krefting (1991:217) propose that neutrality in qualitative research should consider the neutrality of the data, rather than that of the researcher, and thus suggested confirmability as the strategy to achieve neutrality. In this study, triangulation and reflexivity were employed to achieve confirmability (Krefting, 1991:221-222).

\section{Limitations of the study}

Possible limitations of the study can be attributed to the following main areas: the preconceptions of the researcher, the qualitative nature of the study and the utilisation of purposive sampling. The reality that no researcher enters a study tabula rasa but has personal and professional knowledge of the subject area under investigation, contributes to approaching the study with certain preconceived ideas or assumptions. Secondly, the utilisation of purposive sampling in the context of qualitative research limits the generalisability of the findings (Creswell, 1994:111). It is thus acknowledged that the findings of this study may not necessarily be applicable to all Muslim women or women in general who are victims of domestic violence.

\section{DISCUSSION OF FINDINGS}

Data were collected through six in-depth semistructured interviews with six participants. The grandtour question that delineated the focus of this study was as follows: "What are the experiences of Muslim 
Table 1: Biographical profile of research participants

\begin{tabular}{|l|l|l|l|l|l|l|}
\hline $\begin{array}{l}\text { Pseudonym } \\
*\end{array}$ & Age & Occupation & $\begin{array}{l}\text { Number of } \\
\text { children }\end{array}$ & $\begin{array}{l}\text { Length of } \\
\text { marriage }\end{array}$ & $\begin{array}{l}\text { Period } \\
\text { since } \\
\text { divorce }\end{array}$ & $\begin{array}{l}\text { Nature of } \\
\text { abuse }\end{array}$ \\
\hline Aneesah & 50 & Self-employed & 3 & 21 years & 5 years & $\begin{array}{l}\text { Emotional } \\
\text { Financial }\end{array}$ \\
\hline Sihaam & 59 & $\begin{array}{l}\text { Home- } \\
\text { executive }\end{array}$ & 5 & 25 years & 15 years & $\begin{array}{l}\text { Physical } \\
\text { Financial } \\
\text { Emotional }\end{array}$ \\
\hline Amara & 45 & Self-employed & 2 & 9 years & 11 years & $\begin{array}{l}\text { Physical } \\
\text { Emotional } \\
\text { Sexual }\end{array}$ \\
\hline Salma & 23 & BA Student & 1 & $21 / 2$ years & Still married & $\begin{array}{l}\text { Physical } \\
\text { Sexual } \\
\text { Emotional }\end{array}$ \\
\hline Rukshaana & 26 & Teller & 3 & 10 years & Still married & $\begin{array}{l}\text { Physical } \\
\text { Financial } \\
\text { Emotional }\end{array}$ \\
\hline Ruwaida & 50 & $\begin{array}{l}\text { Home- } \\
\text { executive }\end{array}$ & 9 & 30 years & Still married & $\begin{array}{l}\text { Emotional } \\
\text { Financial } \\
\text { Attempted } \\
\text { physical }\end{array}$ \\
\hline
\end{tabular}

* (Pseudonyms will be used in the report in line with the ethical considerations, namely the protection of the privacy of participants and to facilitate confidentiality).

women in the Nelson Mandela Metropole region with regard to domestic violence?"

Subsequently, the open-ended statements and questions mentioned in Phase Four above, were asked at each interview.

The answers to these questions were transcribed verbatim, and analysed according to the eight steps for analysing qualitative generated data provided by Tesch in Creswell (1994:153).

The ensuing discussion on the research findings will be divided, and presented in two sections, namely: a biographical profile of the participants and a discussion on the themes, sub-themes, categories and subcategories that emerged from the process of data analysis, and the consensus discussion between the researchers and an independent coder.

\section{A biographical profile of the research participants}

Table 1 depicts a biographical profile of the participants who took part in this research study.

From Table 1 it becomes clear that domestic violence took place across the life span of the marital relationship, in which these females were the victims of violence. This confirms what Hendrick and Hendrick (1992:184) contend: "Although aggression is present in both sexes, battering of wives by husbands is the phenomenon that occurs most frequently". Dobash, Dobash, Cavanaugh and Lewis (2000:3) state that "the overall pattern of intimate violence is dominated by men as the abusers and women as the abused". It 
can also be noted from Table 1 that women of varying ages and occupations were the victims of domestic violence. Lambert (2000:49) confirms this by stating that "women of all cultures, races, occupations, income levels and ages are abused by husbands, boyfriends, lovers and partners". The nature of abuse experienced by participants is confirmed by literature in that these types of abuse occur in intimate relationships. Keen and Silove (1996:4-5) are of the opinion that "intimate partner violence is a form of trauma occurring within the context of an intimate relationship and which may include emotional, verbal, physical, sexual or financial abuse".

\section{Themes, sub-themes, categories and unique theme: A thematic discussion}

The following themes emerged from the data collected:

- types of abuse experienced by participants;

- feelings/emotional reactions experienced by participants as a result of abuse;

- precipitating factors contributing to domestic violence experienced by participants;

- motivation for maintaining the abusive relationship;

- coping mechanisms to remain in or to leave the abusive relationship, and

- advice from participants to others in abusive relationships.

Each of these themes with its accompanying subthemes, categories and sub-categories, will be discussed in the remainder of this presentation, and be subjected to a literature control.

\section{Theme 1: Types of abuse experienced by participants}

The participants experienced various types of abuse, which the researchers has divided into two subthemes, namely: primary abuse, which included physical abuse, sexual abuse, emotional and economic abuse; and secondary abuse, which included abuse experienced at the hands of the family, the religion and the community. The former is confirmed by Keen and Silove (1996:4-5), who state that "intimate partner violence is a form of trauma occurring within the context of an intimate relationship and which may include emotional, verbal, physical, sexual or financial abuse" (compare Hendrick \&
Hendrick, 1992:184).

In Table 2 the types of abuse experienced by the participants are indicated, as well as excerpts from the interviews to support the various sub-themes/categories.

Burgdorff and Block (1996:84) confirm that emotional abuse is the most damaging, stating that emotional abuse is a common problem that few people talk about, and that the bruises of this kind of abuse may not be in black or blue but are very deep. Alpaslan (1997:123) states that "the parents/family will always be inclined to take the part of their child and to become antagonistic towards son/daughter-in-law". Studies have shown how religious institutional practices reinforce and sanction violence against women, by adhering to strict gender stereotypical roles and discouraging divorce (Giesbrecht \& Sevcik, 2000:229248; Govinden, 1997:23-28).

\section{Theme 2: Feelings/emotional reactions experienced by participants as a result of the abuse}

Research undertaken by Blackman (1989:234) showed that abused women experience feelings of anger, guilt, panic, hatred, hurt and unworthiness. The participants experienced a number of feelings, which resulted from the abuse. These included: nervousness and fear; feeling insulted and belittled; anger and hurt; feelings of hatred and vengefulness; unhappiness; feeling numb and tired; feeling worthless, taken for granted, mistreated, unloved and trapped; feeling guilt; feeling sorry, feeling despondent, feeling suicidal, and sometimes feeling hopeful.

Table 3 depicts the feelings the participants experienced as a result of the abuse. (Table 3 is on page 47).

Motingoe, Gilchrist and Keen (1996:34) state that a battering relationship creates severe psychological, as well as physical trauma. According to Dutton (1997), battered women's reactions to violence and abuse vary, and include emotional reactions such as fear, anger, sadness, and changes in beliefs and attitudes about the self, others and the world, such as distrust, self-blame and symptoms of psychological distress and dysfunction such as depression, anxiety, sleep problems and substance abuse. 
Table 2: Types of abuse and excerpts from interviews

\begin{tabular}{|c|c|c|}
\hline Sub-theme & Categories & Excerpt from the interviews \\
\hline Primary abuse & $\begin{array}{l}\text { Sexual abuse } \\
\text { Emotional/ } \\
\text { psychological abuse } \\
\text { Economic abuse }\end{array}$ & $\begin{array}{l}\text { "He hit me with a Coke bottle, the can. He broke } \\
\text { my jaw. I couldn't speak for three months, Razia, } \\
\text { toe is ek gewire, I couldn't eat nothing." } \\
\text { "... he was raping me and all this and that, doing } \\
\text { funny things and all that, which I found very weird." } \\
\text { "He would ... pass the remark of the fat or the } \\
\text { wrinkles or you getting so old or you, you know, } \\
\text { looking so ugly." } \\
\text { "He doesn't give me money, by the way, he doesn't } \\
\text { give me money so that's another thing right, it's to } \\
\text { cut you, you see, they make you so dependent on } \\
\text { them and there's nothing you can do about it you } \\
\text { see." }\end{array}$ \\
\hline Secondary abuse & $\begin{array}{l}\text { Abuse by in-laws } \\
\text { Abuse by family-of- } \\
\text { origin } \\
\text { Abuse by religion }\end{array}$ & $\begin{array}{l}\text { "She [his mother] took his part, she rather made } \\
\text { trouble for me, she tells everyone I'm making } \\
\text { trouble and I'm a liar and all you know." } \\
\text { "And the worst part was, your family never stood } \\
\text { with you, that was the worst abuse that I could } \\
\text { have, is when your family knew what you were } \\
\text { going through and still they weren't there for you." } \\
\text { "Muslim women, let me tell you, Muslim women } \\
\text { which I've noticed - I'm not a born Muslim, let me } \\
\text { tell you, I'm a revert, but what I have experienced I } \\
\text { can refer you to many Muslim women that are in } \\
\text { similar situations now, not exactly like mine, but } \\
\text { basically controlled by the man and that type of } \\
\text { thing, but they are afraid to speak, you see. Muslim } \\
\text { women are taught, or I don't know brought up } \\
\text { maybe, that way that you know they can't talk, they } \\
\text { mustn't talk you know, and it's so wrong, you know } \\
\text { because that is why the men continue going on." }\end{array}$ \\
\hline
\end{tabular}


Table 3: Feelings experienced as a result of the abuse

\begin{tabular}{|c|c|}
\hline Sub-theme & Excerpt from the interviews \\
\hline Nervousness and fear & $\begin{array}{l}\text { "He would come home from work then l'm just a bundle of nerves } \\
\text { with children and all." }\end{array}$ \\
\hline $\begin{array}{l}\text { Feeling insulted and } \\
\text { belittled }\end{array}$ & $\begin{array}{l}\text { "Because you have no say, you're like a child, you know, and yet } \\
\text { you a mother, you a woman and you know you feel intelligent } \\
\text { enough, you wanna do something with your life but you can't." }\end{array}$ \\
\hline Feelings of anger and hurt & $\begin{array}{l}\text { "Well, I felt sad and hurt that the man who says he loves me could } \\
\text { do this to me. I also felt angry at him." }\end{array}$ \\
\hline $\begin{array}{l}\text { Feelings of hatred and } \\
\text { wish for revenge }\end{array}$ & $\begin{array}{l}\text { "I don't even want to look at him because I hate him so much, he } \\
\text { can die in front of me, ooh, because he did treat us so bad, really." }\end{array}$ \\
\hline & $\begin{array}{l}\text { "I felt the need to hurt him back and then there was a time when I } \\
\text { just started saying the same things back to him about his family." }\end{array}$ \\
\hline Feelings of unhappiness & $\begin{array}{l}\text { "... you won't know the mental strain to be under and to be living, } \\
\text { like l'm living a lie, because I must give a smile, but inside l'm } \\
\text { dying. I feel miserable, some days l've got to pep myself up, you } \\
\text { know...." }\end{array}$ \\
\hline Feeling numb and tired & $\begin{array}{l}\text { "Up until now, Razia, you can put a pin in me, I don't even feel it. } \\
\text { You can put a pin here [below the eye] I don't feel nothing. Ek is } \\
\text { dood, dood, dood van al die abuse. Ek run van my dag af, I } \\
\text { thought, no, man, l'm tired now. No man, it can't go on - you get } \\
\text { tired, somehow or other you do get tired." }\end{array}$ \\
\hline $\begin{array}{l}\text { Feelings of worthlessness, } \\
\text { taken for granted, } \\
\text { mistreated and unloved }\end{array}$ & "I felt like he took me for granted." \\
\hline Feeling trapped & $\begin{array}{l}\text { "A lot of times I also felt like I was trapped in the marriage because } \\
\text { I was forced to stay." }\end{array}$ \\
\hline
\end{tabular}




\begin{tabular}{|l|l|}
\hline Feelings of guilt & $\begin{array}{l}\text { "That was also one of his tricks, anything that goes wrong, even if } \\
\text { it's like with the children, financial, or a problem which is in any } \\
\text { marriage, he would turn around and make me feel guilty. And I } \\
\text { would believe, feel that I was to be blamed for whatever happened." } \\
\text { "I feel that it's the person that you love and he was, he had, very, } \\
\text { very fine ways, he can be a real gentleman. He is one, in spite of } \\
\text { what he does, he's a gentleman, you know, but that comes from his } \\
\text { father's side, but really what he does is, I don't know, I feel sorry for } \\
\text { him." } \\
\text { Feeling despondent } \\
\text { "... but it's very difficult to tell somebody, Muslim or a Christian, } \\
\text { 'believe in God', because at that time you think God has deserted } \\
\text { you too. It's like where are you? You supposed to help me out of } \\
\text { this shit and you know what I mean. Where is God then? You know } \\
\text { what I mean." } \\
\text { "There was a time that I wished Allah would take me from this } \\
\text { doenya [earth] because I couldn't take it anymore." } \\
\text { "... I also thought things are gonna change you know, you were } \\
\text { right you know, live in hope and not for your sake as a woman, as a } \\
\text { mother for her children's sake ... his children are going to live with } \\
\text { a stigma, you see, of a broken home, to save them this is all the } \\
\text { reasons I live in hope." }\end{array}$ \\
\hline
\end{tabular}

\section{Theme 3: Precipitating factors contributing to domestic violence experienced by participants}

All the participants tried to make sense of the abuse in terms of the precipitating factors contributing to the domestic violence. The following explanations were offered by them: alcohol, money, power, an identity crisis and low self-esteem as the precipitating factors contributing to the domestic violence.

Table 4 illustrates the precipitating factors contributing to domestic violence experienced by participants.

According to a study done by Jewkes (2002), alcohol consumption is associated with increased risk of all forms of interpersonal violence and it is thought to reduce inhibitions, cloud judgement, and impair ability to interpret social cues. However, the author maintains that biological links between alcohol and violence are complex. Rice (in Alpaslan, 1997:115) states that money, with specific reference to acquiring and spending it, can be a source of great conflict in the marital relationship. Schornstein (1997:46) confirms that an abusive relationship is primarily characterised by power and control. The abusive partner has all the power and seeks to exercise control over his partner. Literature by Jewkes (2002:1423) confirms that violence is used to resolve a crisis of male identity, at times caused by poverty or an inability to control women. Men who batter their wives have been found to have low self-esteem and a vulnerable self-concept (compare Gelles \& Cornell, 1988:71 and McCue, 1995:108).

Theme 4: Motivation for maintaining abusive relationship

The participants identified the following factors which 
Table 4: Precipitating factors contributing to domestic violence

\begin{tabular}{|c|c|}
\hline Sub-theme & Excerpts from interviews \\
\hline $\begin{array}{l}\text { Alcohol as a precipitating } \\
\text { factor leading to domestic } \\
\text { violence }\end{array}$ & $\begin{array}{l}\text { "Then he used to hit me, but he was mostly drunk when it } \\
\text { happened." }\end{array}$ \\
\hline $\begin{array}{l}\text { Money as a precipitating factor } \\
\text { leading to domestic violence }\end{array}$ & $\begin{array}{l}\text { "He used to work, Razia, no money, but he want to eat van die } \\
\text { beste ook, and the fighting was always out of money, food and } \\
\text { money, but he never use to give money." }\end{array}$ \\
\hline $\begin{array}{l}\text { Power as a precipitating factor } \\
\text { leading to domestic violence }\end{array}$ & $\begin{array}{l}\text { "And I stayed strong because it was mentally draining to live } \\
\text { under such a domineering man, it's like being married to your } \\
\text { father, you know." }\end{array}$ \\
\hline $\begin{array}{l}\text { Identity crisis as a precipitating } \\
\text { factor leading to domestic } \\
\text { violence }\end{array}$ & $\begin{array}{l}\text { After two years Amara discovered that her husband was gay. } \\
\text { When his extra-marital gay affairs were not going well, he would } \\
\text { take his frustrations out on her. She explained: "but when his } \\
\text { love life was OK in the street [referring to his affairs] then he } \\
\text { doesn't interfere with me, but as soon as something goes wrong } \\
\text { with that affair, he starts taking it out on me." }\end{array}$ \\
\hline $\begin{array}{l}\text { Low self-esteem as a } \\
\text { precipitating factor leading to } \\
\text { domestic violence }\end{array}$ & $\begin{array}{l}\text { "... he still said to me, discourage me and said: "Why do you } \\
\text { want to go to varsity? If you go to varsity I know you will never } \\
\text { look at me again'." }\end{array}$ \\
\hline
\end{tabular}

caused them to remain in their abusive marital relationships: patriarchal belief systems; economic dependence; staying for the sake of the children; fear of rejection; protecting his image; and hope for change.

Table 5 depicts the participants' motivation for maintaining the abusive relationship.

Hendrick and Hendrick (1992:185) confirm that economic, cultural and relational constraints may keep wives with their abusive husbands. The deeply entrenched belief that children need both their parents keeps many women trapped in violent relationships (Maconachie in Glanz \& Spiegel, 1996:161). Berlinger (2001:60) confirms that, if the abuser has a good image in public, women may be reluctant to speak out about the abuse. Literature has also shown that women remain in abusive relationships because they believe that the perpetrator might change (Ganley in Kemp, 1998:243).

\section{Theme 5: Coping mechanisms to remain in or leave the relationship}

The participants' narratives demonstrated that there were times that they felt they were able to cope with what was happening in their marriages, and other times when they saw themselves as not being able to cope. Their coping strategies can be divided into two sub-themes, namely those coping mechanisms which enabled the woman to stay in the abusive relationship, and those which enabled her to leave the abusive relationship.

In Table 6 the coping mechanisms cited by the participants in the abusive relationship are indicated.

Related research has shown that abused women find 
Table 5: Participants' motivation for maintaining the abusive relationship

\begin{tabular}{|c|c|}
\hline Sub-theme & Excerpts from interviews \\
\hline Patriarchal belief systems & $\begin{array}{l}\text { "... In our era our parents brought us up to respect males you } \\
\text { know, whatever, women didn't really have a say you know, but I } \\
\text { think he exploited that from the very beginning because, looking } \\
\text { back in my life now, I realise how I was to blame because I allowed } \\
\text { too many things to happen, but in ignorance because I didn't know } \\
\text { of any better...." }\end{array}$ \\
\hline Economic dependence & $\begin{array}{l}\text { "... I'm immobile. I am totally dependent on him, so you can } \\
\text { imagine what he does. He's ten times worse than he has ever been } \\
\text {... he doesn't give me money, by the way he doesn't give me } \\
\text { money, so that's another thing, right, it's to cut, you see, they make } \\
\text { you so dependent on them and there's nothing you can do about } \\
\text { it." }\end{array}$ \\
\hline $\begin{array}{l}\text { Staying for the sake of the } \\
\text { children }\end{array}$ & $\begin{array}{l}\text { "Well I felt, you know, like it is when you have children, you hang in } \\
\text { there because you don't want to give up for the sake of the children } \\
\text { because you don't want them to go through, you know, like broken } \\
\text { marriages." }\end{array}$ \\
\hline Fear of rejection & $\begin{array}{l}\text { "... nobody would believe me if I told them what character he really } \\
\text { is, because on the outside he was angel. All he needed was a pair } \\
\text { of wings!" }\end{array}$ \\
\hline Protecting his image & $\begin{array}{l}\text { "... I can walk away tomorrow and still be the same person and if I } \\
\text { walk away l'm going to expose him. The people are going to say } \\
\text { 'Did his wife leave him?' and his children are going to live with a } \\
\text { stigma." }\end{array}$ \\
\hline Hope for change & $\begin{array}{l}\text { "... ek het vir myself gesê ek gaan die wilskrag hê om hom reg te } \\
\text { maak. Jy weet Inshaalah [if Allah wills] hy sal regkom." }\end{array}$ \\
\hline
\end{tabular}

religious practice a source of strength in their lives, as well as an influence to remain in the abusive relationship (Boonzaaier, 2001:8). Women who lack economic independence are most likely to remain in the abusive relationship (Strube \& Barbour, 1983:786).

Theme 6: Advice from participants to others in abusive relationships

The participants offered the following advice to women in abusive relationships:

- Have faith/Keep your faith.

"Always believe in Allah because Allah hears your duahs [prayers)".

- Break the silence surrounding the abuse. One participant suggested that women confide in someone that they trust, and another one advised women to join a support group, "because talking makes one feel better". 
Table 6: Coping mechanisms cited by the participants in the abusive relationship

\begin{tabular}{|c|c|c|}
\hline Sub-theme & Category & Excerpt from interview \\
\hline \multirow[t]{4}{*}{$\begin{array}{l}\text { Coping mechanisms } \\
\text { which enabled } \\
\text { participants to stay in } \\
\text { the abusive relationship }\end{array}$} & $\begin{array}{l}\text { Faith in God and } \\
\text { prayer }\end{array}$ & $\begin{array}{l}\text { "I really feel good that I was in it. The thing that } \\
\text { kept me, like, strong, like, to stand it all and to be } \\
\text { whoever I was then, was, like, my salaah } \\
\text { [prayer]." }\end{array}$ \\
\hline & $\begin{array}{l}\text { Relationship with } \\
\text { children }\end{array}$ & $\begin{array}{l}\text { "But daar is dae wat ek kon gecope het met dit, } \\
\text { and daar's dae wat ek dit nou nie kon gevat het } \\
\text { nie, en meeste het dit my gevat in die werk in, } \\
\text { dan sal ek so intens sit en dink, dan moet ek } \\
\text { besighou, anderste as ek stilsit gaan ek baie } \\
\text { dink." } \\
\text { "... I get involved with the children's things, you } \\
\text { know, and we, l've got a very good relationship } \\
\text { with my children. We like lay on the bed and chat } \\
\text { and talk, you know ... l'm becoming more } \\
\text { stronger, you know, 'cause I need to be that for } \\
\text { them, you see." }\end{array}$ \\
\hline & Internal strength & $\begin{array}{l}\text { "I was also a very strong person. I never felt } \\
\text { afraid of my husband, you know, and in that way I } \\
\text { didn't show him that he was breaking me down, I } \\
\text { rather showed him I'm not afraid." }\end{array}$ \\
\hline & Retaliation & $\begin{array}{l}\text { "I felt the need to hurt him back and then there } \\
\text { was a time when I just started saying the same } \\
\text { things back at him about his family. And oh boy! } \\
\text { He hated that, but it made me feel better." }\end{array}$ \\
\hline $\begin{array}{l}\text { Coping mechanisms } \\
\text { which enabled } \\
\text { participants to leave the } \\
\text { abusive relationship }\end{array}$ & $\begin{array}{l}\text { Faith in God } \\
\text { Financial } \\
\text { independence }\end{array}$ & $\begin{array}{l}\text { "... you must be able to want to get out of it and } \\
\text { that is the first step you take, OK, not the first } \\
\text { step, the first step is your Imaan [faith] you must } \\
\text { have Imaan and yaken [believe/trust] in Allah so } \\
\text { that you can say Allah is going to help me even if } \\
\text { it is not now, he is going to ...." } \\
\text { "... If I can manage to maintain myself, my home } \\
\text { and my children, then I might as well opt out of } \\
\text { the marriage." }\end{array}$ \\
\hline
\end{tabular}


- Know your rights as a woman in Islam.

Goosen and Schaik (1998:7) state that women need to know their rights and be empowered. Women and children who feel empowered will insist that they be treated with respect. The following excerpt from the interviews support this: "Also be aware of your rights as a Muslim woman and wife, read up on your religion and know your rights so that when you approach a Sheikh, you can stand up to them and ask questions".

- Decide to get out.

The following excerpt supports this: "Get yourself independent, not dependent. Go for your driver's licence".

- Seek therapy/counselling.

"Often the work against domestic violence is concentrated on helping the women. This is important, but it is as important to work with the men if we want the violence to come to an end. This is why counselling for men is necessary" (Lorentzen, 1998:89). This is supported by one of the participants' utterances: "... if you choose to give him a chance don't just accept his words that he will change because action speaks louder than words. Let him get help".

\section{CONCLUSIONS AND RECOMMEN- DATIONS}

The conclusions that can be made based on the research findings and the literature verification are as follows:

- The participants found the emotional abuse to be the worse kind of abuse they could have experienced, because the psychological effects of the abuse remained with them for some time.

- As a result of the abuse, participants experienced a range of feelings which had a negative impact on them.

- All the participants were able to cope with their abusive marriage because of their faith in God and prayer.

- The participants encouraged other women in similar situations to empower themselves and take an active stance against domestic violence.
- The participants, as well as their husbands, had certain belief systems, which influenced them and perpetuated the abuse: Both women and men had been raised according to certain traditional and cultural norms, which influenced the interpretation of their roles in the abusive relationship. This finding affirms the opinion of Hoff (1990:42) that a woman's decision to stay is a result of cultural rules she has learned about marriage and a woman's role as traditionally defined.

- The community also influence the woman's decision to stay, as she fears rejection because members of the community might not believe her.

- Women are disempowered in terms of finances and concerning awareness of their rights in Islam. This compels them to stay in the abusive relationship.

Based on these conclusions the following recommendations are made:

\section{Holistic awareness initiatives}

It is recommended that the patriarchal belief systems of people change, so that future generations will not grow up with the same beliefs. This could be achieved through educational workshops and talks on gender issues, such as the rights of men and women in the marital relationship; religious perspectives of Muslim marriages; role definitions and stereotypes.

\section{Educating parents}

In an effort to prepare adults for their parental responsibility, it is important to enable parents to confront their own beliefs regarding marriages in the context of Islam. This will enable parents to put across a more realistic perspective to their children.

\section{Empowerment of women}

- It is recommended that women be empowered so that they can be independent. This could be achieved by the creation of economic empowerment programmes within the community, implemented by community leaders such as those prominent ladies who were 
identified as the gatekeepers in this research endeavour. Women should also be empowered with regard to knowledge of the Faith, and of their rights as Muslim women or wives. The Sheiks and Imams could accomplish this in the community when they meet with couples for marriage preparation prior to the wedding. Marriage must be seen as a partnership, and marriage contracts should specify a commitment to an abuse-free, violence-free family.

- It is recommended that the Muslim community be sensitised to the reality of domestic violence in Muslim marriages so that abused women can feel supported by the wider community. This can be achieved by the planning and presentation of awareness programmes by professionals such as social workers and psychologists in the community.

\section{Preparation for marriage}

It is recommended that, prior to their wedding, engaged couples attend marriage preparation courses, which should be developed and presented by professionals in the Muslim community, as well as by Sheiks and Imams. This would ensure that religious beliefs could be addressed as well as broader relationship issues.

\section{Support services for abused women}

It is recommended that support structures such as a "safe haven" and a place where women can be counselled, be created, to help women who fall prey to domestic violence. There is a need for these structures which can provide comprehensive and centralised intervention.

\section{Public education and awareness}

- It is recommended that community awareness talks or workshops be held in the community in order to educate them about domestic violence from an Islamic perspective. Various topics could be covered, such as: domestic violence in general (which could be presented by a social worker in the community); domestic violence in Islam-prevalence; Islamic perspective and women's rights (which could be presented by a Sheik or Imam); and how violence in the home affects children (which could be presented by a psychologist).

- It is recommended that professionals use these research findings to enhance their interventions with the target population.

- It is also recommended that professionals in the helping professions should focus not only on the women in the abusive relationship, but should focus also on the children, because they are the secondary victims of abuse.

\section{Intervention of religious leaders}

It is recommended that the Sheiks and Imams treat situations of domestic violence as serious, and be sensitive to the women who approach them. This could be achieved by acting promptly when receiving a telephone call to go out and assess a situation of domestic violence. Sheiks and Imams must consult a counsellor about knowing how to assess the levels of domestic violence and how to counsel abused women, and how to develop protection plans.

\section{Future research}

Finally, it is recommended that further research be done on the effects of domestic violence on children in Muslim marriages, and on Muslim men's perceptions of their roles in the marriage, as well as those of their wives.

\section{REFERENCES}

ALKHATEEB, S (n.d.): Ending domestic violence in Muslim families. [Online]. Available: http://www.steppingtogether.org/article_02.html [Accessed 18 July 2001].

ALPASLAN, N 1997: Methods and means for a meaningful marriage: A preparation for marriage and marriage guidance workbook. Cape Town: Kagiso.

ANONYMOUS n.d.: Muslims against family violence [Online]: Available: http://www.steppingtogether.org/projects_mafv.html [Accessed 18 July 2001].

ANONYMOUS 2001: An Islamic perspective on violence against women. [Online]. Available: http//www.awaj.com/articles/ violence_mwl.html [Accessed 18 July 2001].

BADAWI, J n.d.: Wife beating? [Online] Available: http:// www.zawaj.com/articles/badawidomestic.html [Accessed 18 July 2001]. 
BERLINGER, JS 2001: Domestic violence. Nursing, 31(8):60.

BLACKMAN, J 1989: Intimate violence: A study of injustice. New York: Colombia University Press.

BOONZAAIER, F 2001: Woman abuse: Exploring women's narratives of violence and resistance in Mitchell's Plain. Cape Town: UCT.

BURGDORFF, L \& BLOCK, JL 1996: Invisible bruises. Good Housekeeping, 222(5).

CHANG, VN 1996: I just lost myself: Psychological abuse of women in marriage. London: Praeger.

CHAUNDRY, MS 1991: Women's rights in Islam. Lahore: Ashraf Printing Press.

COHEN, L \& MANION, L 1994: Research methods in education. London: Routledge.

CRESWELL, JW 1994: Research design: Qualitative and quantitative approaches. Thousand Oaks: Sage.

DE VOS, AS; STRYDOM, H; FOUCHé, CB; POGGENPOEL, M; SCHURINK M \& SCHURINK, W 1998: Research at grass roots: A primer for the caring professions. Pretoria: JL van Schaik Academic. DENZIN, NK \& LINCOLN, YS 1998: The landscape of qualitative research: Theories and issues. Thousand Oaks: Sage.

DOBASH, RE; DOBASH, RR; CAVANAGH, K \& LEWIS, R 2000: Changing violent men. London: Sage.

DOMESTIC VIOLENCE ACT, No. 116 of 1998. Pretoria: Government Printing Works.

DUTTON, MA 1997: Critique of the 'Battered Woman Syndrome' Model. [Online]. Available: http://www.fascination.com/pub/ywcas-ash/ domestic.htm [Accessed 19 October 2002].

GELLES, RJ \& CORNELL, CP 1988: Intimate violence in families. New York: Simon and Schuster.

GIESBRECHT, N \& SEVCIK, I 2000: The process of recovery and rebuilding among abused women in the conservative evangelical subculture. Journal of Family Violence, 15(3):229-249.

GLANZ, LE \& SPIEGEL, AD 1996: Violence and family life in a contemporary South Africa: Research and policy issues. Pretoria: HSRC.

GOOSEN, V \& SCHAIK, F 1998: Women making a fresh start: A guide for women leaving abusive relationships. Lenasia: Nisaa Institute for Women's Development.

GOVINDEN, DB 1997: 'Domination to rule': The abuse of women in Christian homes. Journal of Constructive Theology, 3(2):23-28. HAGUE, G \& MALOS, E 1998: Domestic violence: Action for change. England: Clarion.

HENDRICK, SS \& HENDRICK, C 1992: Linking loving and relating; $2^{\text {nd }}$ edition. Pacific Grove: Brooks/Cole.

HENDRICKS, S (n.d.): Authority and the abuse of power in Muslim marriages. [Online]. Available: http://www.zawaj.com/articles/ marriage_abuse_power.html [Accessed 18 July 2001].

HOFF, L 1990: Battered women as survivors. London: Routledge. JEWKES, R 2002: Intimate partner violence: Causes and preven- tion. Lancet, 359(9315):1523-1429.

KEEN, J \& SILOVE, M 1996: The trauma of domestic violence. Trauma Review, 4(2):4-5.

KEMP, A 1998: Abuse in the family: An introduction. London: Brooks/ Cole.

KREFTING, L 1991: Rigor in qualitative research: The assessment of trustworthiness. American Journal of Occupational Therapy, 45(3):214-222.

LAMBERT, LC 2000: Economic context and multiple abuse techniques. Violence against Women, 6(1):49-67.

LORENTZEN, J 1998: Violence without a subject. Agenda, 37:8689.

McCUE, ML 1995: Domestic violence: A reference handbook. California: ABC-CLIO.

MEMON, K (n.d.): Wife abuse in the Muslim community. [Online]. Available: http://www.steppingtogether.org/article_01.htm [Accessed 18 July 2001].

MOTINGOE, N; GILCHRIST, A \& KEEN, J 1996: Domestic violence: psychological aspects of women who experience spouse abuse. Trauma Review, 4(2):3-5.

NEUMAN, WL 1994: Social research methods: Qualitative and quantitative approaches; $2^{\text {nd }}$ edition. Boston: Allyn \& Bacon.

PARK, YJ; FEDLER, J \& DANGOR, Z 2000: Reclaiming women's spaces: New perspectives on violence against women and sheltering in South Africa. Johannesburg: Nisaa Institute for Women's Development.

QURAAN STUDY AND RESEARCH FOUNDATION 1999: A complete course on the psychology, sociology and philosophical teachings of the Quraan and Hadith. Johannesburg.

RUBIN, A \& BABBIE, E 1997: Research methods for social work; $3^{\text {rd }}$ edition. Boston: Brooks/Cole.

SCHORNSTEIN, SL 1997: Domestic violence and health care: What every professional needs to know. London: Sage.

SHAIKH, SS 1996: Battered women in Muslim communities in the Western Cape: Religious constructions of gender, marriage, sexuality and violence. Cape Town: UCT Religious Studies.

SILVERMAN, D 2000: Doing qualitative research: A practical handbook. London: Sage.

STRAUSS, A \& CORBIN, J 1998: Basics of qualitative research: Techniques and procedures for developing grounded theory; $2^{\text {nd }}$ edition. Thousand Oakes, California: Sage.

STRUBE, MJ \& BARBOUR, LS 1983: The decision to leave an abusive relationship: Economic dependence and psychological commitment. Journal of Marriage \& Family, 45(4):785-793.

TERRE BLANCHE, M \& DURRHEIM, K 1999: Research in practice: Applied methods for the social sciences. Cape Town: University of Cape Town Press.

TSHIWULA, L 1998: Crime and delinquency. Pretoria: Kagiso.

TUTTY, LM; ROTHERY, MS \& GRINNELL, RM (Jr.) 1996: Qualitative 
research for social workers: Phases, steps and tasks. London: Allyn \& Bacon.

VINCENT, JP \& JOURILES, EN 2000: Domestic violence: Guidelines for research - Informed practice. London: Jessica Kingsley.

YEGIDIS, BL \& WEINBACH, RW 1996: Research methods for social workers; $2^{\text {nd }}$ edition. Boston: Allyn \& Bacon. 